\title{
The Evolution of Pneumatic Foramina in Pterosaur Vertebrae
}

\section{RICHARD BUCHMANN and TAISSA RODRIGUES}

Laboratório de Paleontologia, Departamento de Ciências Biológicas, Centro de Ciências Humanas e Naturais, Universidade Federal do Espírito Santo, Avenida Fernando Ferrari, 514, Goiabeiras, 29075-910 Vitória, ES, Brazil

Manuscript received on September 24, 2018; accepted for publication on January 18, 2019

How to cite: BUCHMANN R AND RODRIGUES T. 2019. The Evolution of Pneumatic Foramina in Pterosaur Vertebrae. An Acad Bras Cienc 91: e20180782. DOI 10.1590/0001-3765201920180782.

\begin{abstract}
Pterosaurs possess skeletal pneumatization, which can be assessed externally through the observation of pneumatic foramina. These foramina vary in position, shape, and number among taxa. Here we propose new characters referring to the position and number of pneumatic foramina present in cervical and dorsal vertebrae of pterosaurs. A cladistic analysis was performed after first-hand study of material in collections and using data from the literature in order to test these new characters for homology, and they were subsequently mapped in a strict consensus tree. The analysis resulted in nine equally parsimonious trees with 215 steps each. The strict consensus tree obtained does not present significant differences in relation to trees obtained in previous studies. The mapping performed identified that most pneumatic foramina evolved independently in several lineages, and only two of the eight added characters appeared once in the evolution of pterosaurs. In general, pneumatic foramina were more common in the Dsungaripteroidea, however, the flattened preservation of non-pterodactyloids and in the Archaeopterodactyloidea often precludes their visualization, and therefore the presence of vertebral pneumatization may be broaden with the discovery of new, better preserved specimens.
\end{abstract}

Key words: Pterosauria, phylogeny, axial skeleton, skeletal pneumatization.

\section{INTRODUCTION}

Pterosaurs are known as the first vertebrates to develop the ability to fly actively. This is possible due to the presence of an extremely specialized skeleton with unique features, such as the presence of wings and of pneumatic bones, a condition analogous to birds (Nesbitt 2011) which considerably decreases bone mass, reducing the weight of the animal. Internal bone pneumatization

Correspondence to: Richard Buchmann

E-mail: richard_buchmann@hotmail.com

ORCid: http://orcid.org/0000-0003-4428-9224

* Contribution to the centenary of the Brazilian Academy of Sciences. can be inferred by the observation of external structures, such as the pneumatic foramina, which are connected to internal cavities.

Besides pterosaurs and extant birds, postcranial pneumatization is also observed in the Sauropodomorpha and non-avian Theropoda (O’Connor 2006, Butler et al. 2012), raising questions about the evolution of this system in archosaurs (Butler et al. 2012). As some archosauriforms, such as Erythrosuchus, have limited evidence of pneumatization such as foramina and fossae that do not contact pneumatic chambers, Butler et al. (2012) did not exclude the possibility of skeletal pneumatization being plesiomorphic for Archosauria. 
In birds, postcranial pneumatization is associated with the presence of air sacs, which allow the invasion of air inside the bone. Considering the role of pneumatic structures in avian lung ventilation, its presence in pterosaurs suggests the existence of a respiratory system analogous to that present in birds (Claessens et al. 2009).

Postcranial pneumatization in pterosaurs is mostly inferred for the vertebral column, although specimens with a wingspan greater than $2.5 \mathrm{~m}$ also tend to present evidences for pneumatization in the appendicular skeleton (Butler et al. 2009, Claessens et al. 2009). In birds, pneumatic foramina are observed in vertebral regions that do not compromise the bone's integrity, thus varying between taxa (Müller 1908). Possibly the same happened in pterosaurs.

In all phylogenetic proposals so far raised for the Pterosauria, characters referring to the vertebrae are limited mainly to the morphology of midcervicals or the ontogenetic fusion of structures, such as between the atlas and axis and the formation of the notarium (Kellner 2003, Unwin 2003, Wang et al. 2008, Andres et al. 2014) and thus could be further explored. In this aspect, Andres et al. (2014) incorporate new characters referring to the size and proportion of different types of vertebrae, including dorsals and caudals (characters 17 to 21). However, generally, characters on vertebral pneumatization refer only to the presence of pneumatic foramina on the lateral sides of the centrum in the midcervical vertebrae, such as characters 44 in Kellner (2003), 47 in Wang et al. (2008) and 159 in Andres et al. (2014). Andres et al. (2014) proposed a new character on the presence of pneumatic foramina laterally to the neural canal (character 160); however, the occurrence of the pneumatic foramina dorsally to the neural canal, commonly observed in dsungaripteroids, was not discussed. Pneumatic foramina present in dorsal vertebrae were also not included in their analysis.
The present study aims to better understand possible homologies and convergences in the evolution of pneumaticity in Pterosauria.

\section{INSTITUTIONAL ABBREVIATIONS}

MN, Departamento de Geologia e Paleontologia, Museu Nacional, Universidade Federal do Rio de Janeiro, Rio de Janeiro, Brazil; NSM-PV, Division of Vertebrate Paleontology, National Science Museum, Tokyo, Japan; YPM, Yale Peabody Museum of Natural History, New Haven, USA.

\section{MATERIALS AND METHODS}

We used as a base the data matrix from Wang et al. (2008), a dataset which has been updated and corrected several times since its first proposal (Kellner 2003) and therefore likely has fewer, if any, character states incorrectly scored. This data matrix also focused on the Pterodactyloidea, which besides including the largest known pterosaurs (and therefore the ones more prone to possess pneumatization), are generally better preserved, facilitating the visualization of pneumatic foramina and therefore of skeletal pneumatization. In addition, this matrix presented few pterodactyloid terminal taxa in which data regarding the vertebral column data was not preserved and thus would be missing data.

As in the original analysis by Wang et al. (2008), the outgroup was composed by three successive outgroups: Ornithosuchus longidens (Huxley 1877) (the one outgroup defined as such in TNT), Herrerasaurus ischigualastensis Reig, 1963, and Scleromochlus taylori Woodward, 1907. In this analysis, we used the 79 characters and the 46 species analyzed in the original matrix. Here, we considered Anhanguera santanae (Wellnhofer 1985) a nomen dubium, after Pinheiro and Rodrigues (2017) and substituted this species for the specimen AMNH 22555 (Anhanguera sp.), which was previously referred to this taxon. 
Eight characters were incorporated into this matrix; three of them were proposed by Andres et al. (2014) (their characters 158, 159 and 160) and five of them are new (Figure 1). Four of these five were proposed based on codification of nominal variables (Hawkins 2000), referring to either the absence or the presence of pneumatic foramina in cervical and dorsal vertebrae, establishing that characters are attributes that can be proposed each as transformations, being independent of each other (De Pinna 1991).

Character 80: Mid-cervical vertebra, neural arch, lateral surface, pneumatic foramen: absent (0); present (1) (from Andres et al. 2014).

Character 81: Mid-cervical vertebra, centrum, lateral surface, pneumatic foramen: absent (0); present (1) (from Andres et al. 2014).

Character 82: Mid-cervical vertebra, lateral to neural canal, pneumatic foramen: absent (0); present (1) (from Andres et al. 2014).

Character 83: Mid-cervical vertebra, dorsal to neural canal, pneumatic foramen: absent (0); present (1) (new).

Character 84: Posterior cervical vertebra, centrum, lateral surface, pneumatic foramen: absent (0); present (1) (modified from Wang et al. 2008).

Character 85: Cervical vertebra, centrum, lateral surface, quantity of pneumatic foramina: always single (0); more than one (1) (new).

Character 86: Free dorsal vertebra, transverse process, base, pneumatic foramen: absent (0); present (1) (new).

Character 87: Free dorsal vertebra, centrum, lateral surface, pneumatic foramen: (0) absent; present (1) (new).

With respect of the number of lateral pneumatic foramina, we chose not to create a multistate character and assumed that the variation in number probably evolved secondarily to the origin of a lateral foramen. Thus, we opted for contingent coding, in which each attribute is treated as a separated character, as suggested by
Forey and Kitching (2000). Therefore, as character 85 depends on the presence of characters 81 and/or 84 , it is possible to have an inapplicable condition for some terminal taxa. Inapplicable codings were scored as "?", as in the original matrix (Wang et al. 2008). However, in the figures missing data and inapplicable characters related to the characters being investigated are differentiated. Individual variations in which, for instance, a foramen is observed only in one side of the vertebra, were scored as present.

Character 47 of the original matrix, "Pneumatic foramina on the side of centrum in cervical vertebrae", was divided in two characters to consider variations in the pneumatization between mid-cervical and posterior cervical vertebrae (present characters 81 and 84).

The data matrix was edited with Mesquite, version 3.03 (Maddison and Maddison 2015) and the phylogenetic analysis was performed in TNT, version 1.1 (Goloboff et al. 2008). All characters were considered with equal weights and non-addictive. The analysis was performed using Traditional Search with the tree bisectionreconnection (TBR) algorithm, although the software uses both TBR and subtree pruningregrafting (SPR). 5,000 additional random sequence replications were used. The branches were collapsed when their minimum size was zero. Characters regarding vertebral pneumatization were mapped on a strict consensus tree using ACCTRAN optimization.

\section{RESULTS}

The analysis resulted in nine equally parsimonious trees with 215 steps each, longer than the ones found by Wang et al. (2008), who found the most parsimonious trees with 193 steps each. The strict consensus tree recovered the taxa in similar positions as those presented by Wang et al. (2008), except for the formation of a large 

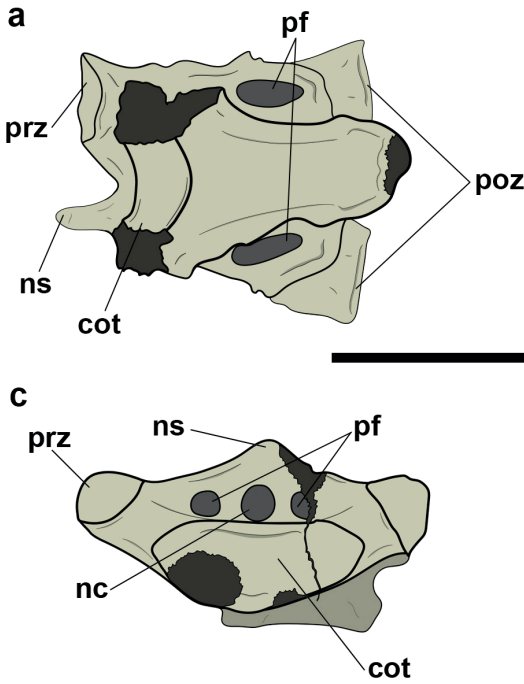

e

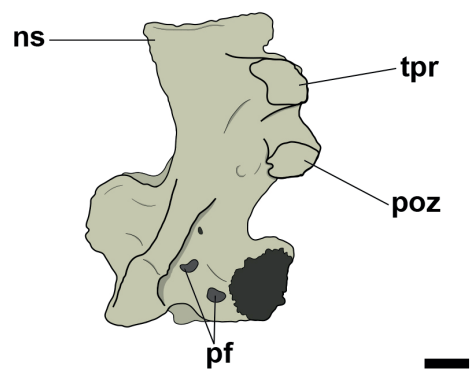

g

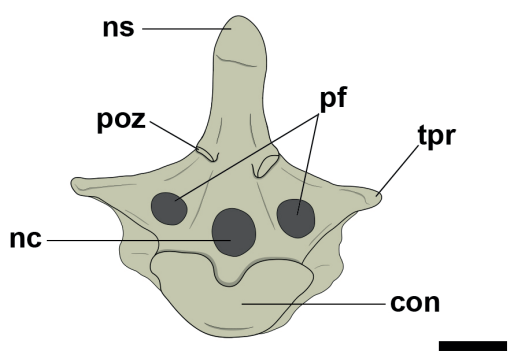

b

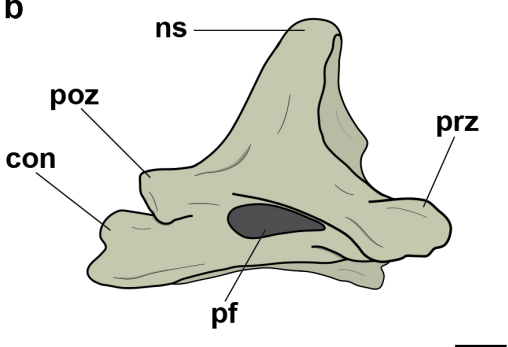

d

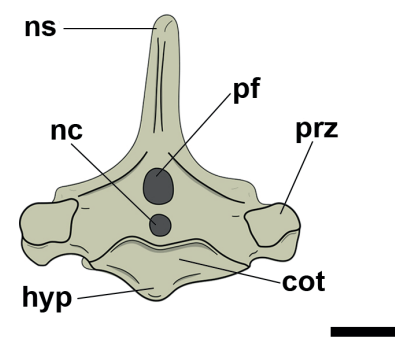

f

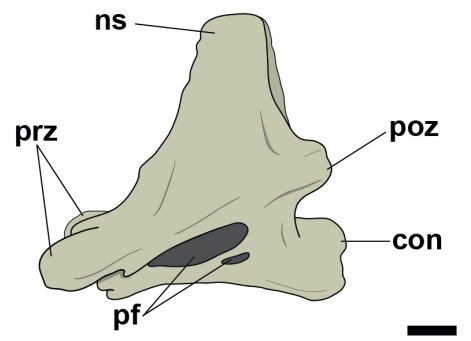

h

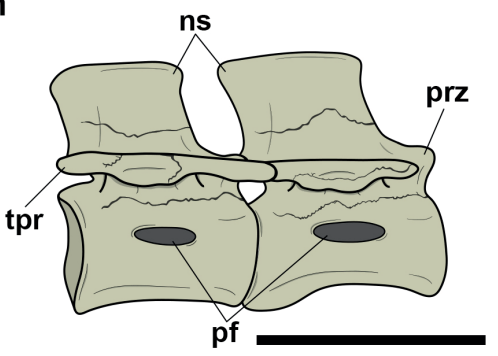

Figure 1 - Pneumatic foramina in pterosaur vertebrae. a) Pneumatic foramina on the lateral surface of the neural arch in a mid-cervical vertebra of Raeticodactylus filisurensis (BNM 14524). b) Pneumatic foramen on the lateral surface of the centrum in a mid-cervical vertebra of Anhanguera piscator Kellner \& Tomida, 2000 (NSM-PV 19892; replica MN $5023-V)$. c) Pneumatic foramina adjacent to the neural canal in a mid-cervical vertebra of Azhdarcho lancicollis (ZIN PH 144/44). d) Pneumatic foramen dorsally to the neural canal in a mid-cervical vertebra of Anhanguera sp. (AMNH 22555). e) Two pneumatic foramina on the lateral surface of the centrum in a posterior cervical vertebra of Thalassodrominae sp. (MN 6566-V). f) Two pneumatic foramina on the lateral surface of the centrum in a mid-cervical vertebra of Anhanguera piscator (NSM-PV 19892; replica MN 5023-V). g) Pneumatic foramina on the bases of the transverse processes in a dorsal vertebra of Anhanguera piscator (NSM-PV 19892; replica MN 5023-V). h) Pneumatic foramina on the lateral surfaces of the centra in two dorsal vertebrae of Dimorphodon macronyx (GSM 1546). Abbreviations: con, condyle; cot, cotyle; hyp, hypapophysis; nc, neural canal; ns, neural spine; pf, pneumatic foramen; poz, postzygapophysis; prz, prezygapophysis; tpr, transverse process. Scale bar: $1 \mathrm{~cm}$. 
polytomy involving Sordes pilosus Sharov, 1971, Preondatylus buffarini Wild, 1984, Scaphognathus crassirostris (Goldfuss, 1861), Dorygnathus bathensis (Theodori, 1830), Dimorphodon macronyx (Buckland, 1829), Peteinosaurus zambelli Wild, 1978, Carniadactylus rosenfeldi Dalla Vecchia, 1995, and the Novialoidea; and Tropeognathus mesembrinus Wellnhofer, 1987 was recovered in a polytomy with the species of Anhanguera.

The presence of pneumatic foramina on the lateral surface of the neural arch in midcervical vertebrae (character 80) is relatively common among non-pterodactyloids, appearing as a synapomorphy of the Novialoidea and with independent origins in non-novialoid species such as Sordes pilosus, Dorygnathus banthensis and Carniadactylus rosenfeldi. The absence of this foramen is synapomorphic for the Pterodactyloidea (Figure 2a). The presence of pneumatic foramina on the lateral surface of the centrum in mid-cervical vertebrae (character 81 ; Figure 2b) is common among the Dsungaripteroidea, being observed in $52.6 \%$ of the analyzed species (26.3\% absent; $21 \%$ missing data). This foramen appeared at least three times in the evolutionary history of pterosaurs: once in the Ornithocheiroidea, being secondarily lost in Istiodactylus latidens (Seeley, 1901) and in the Azhdarchidae, and was also acquired independently in the non-pterodactyloids Sordes pilosus and Dimorphodon macronyx.

The presence of pneumatic foramina on the lateral sides of the neural canal of the mid-cervical vertebrae (character 82) is a synapomorphy of the Dsungaripteroidea, and lost secondarily in AMNH 22555, Tropeognathus mesembrinus and Phobetor parvus (Bakhurina, 1982) (Figure 3a). The presence of pneumatic foramina dorsally to the neural canal in mid-cervical vertebrae (character 83) appeared three times, and only among dsungaripteroids: in the Azhdarchoidea, AMNH 22555 and Pteranodon longiceps Marsh, 1876 (Figure 3b).
The presence of pneumatic foramina on the lateral surface of the centrum of the posterior cervical vertebrae (character 84) appeared as a synapomorphy of the Anhangueridae, with a convergent origin in Rhamphorhynchus muensteri (Goldfuss, 1831), a novialoid non-pterodactyloid, and Azhdarcho lancicollis Nessov, 1984, an Azhdarchidae (Figure $4 \mathrm{a}$ ). The presence of variation in the number of lateral foramina (character 85) was observed only in the Anhangueridae, and was recovered as a synapomorphy of the clade (Figure $4 b$ ).

Among the analyzed specimens, the presence of pneumatic foramina on the base of the transverse process in dorsal vertebrae (character 86) appeared at least four times independently among novialoids: Rhamphorhynchus muensteri, Pteranodon longiceps, Anhangueridae and Azhdarchoidea (Figure 5a). Pneumatic foramina on the lateral surface of the centrum in dorsal vertebrae (character 87 ) were present in only two of the analyzed species: Dimorphodon macronyx and Nurhachius ignaciobritoi Wang et al., 2005 (Figure 5b).

\section{DISCUSSION}

In the pterosaur fossil record, most threedimensionally preserved material belongs to the Dsungaripteroidea (Wellnhofer 1991, Bennett 2001, Averianov 2010, Eck et al. 2011). Nondsungaripteroids are commonly found flattened and/ or articulated (Wellnhofer 1975, Butler et al. 2009), precluding the observation of possible pneumatic foramina, either on the lateral sides of the central or adjacent to the neural canals. This preservation may have influenced the fact that the analysis didn't point out any homologous appearances of the added characters in non-novialoids, suggesting only independent acquisitions in these basal taxa.

Claessens et al. (2009) suggest that in nonpterodactyloids the pneumatization is either limited to the posterior cervical and dorsal vertebrae or it is 
a

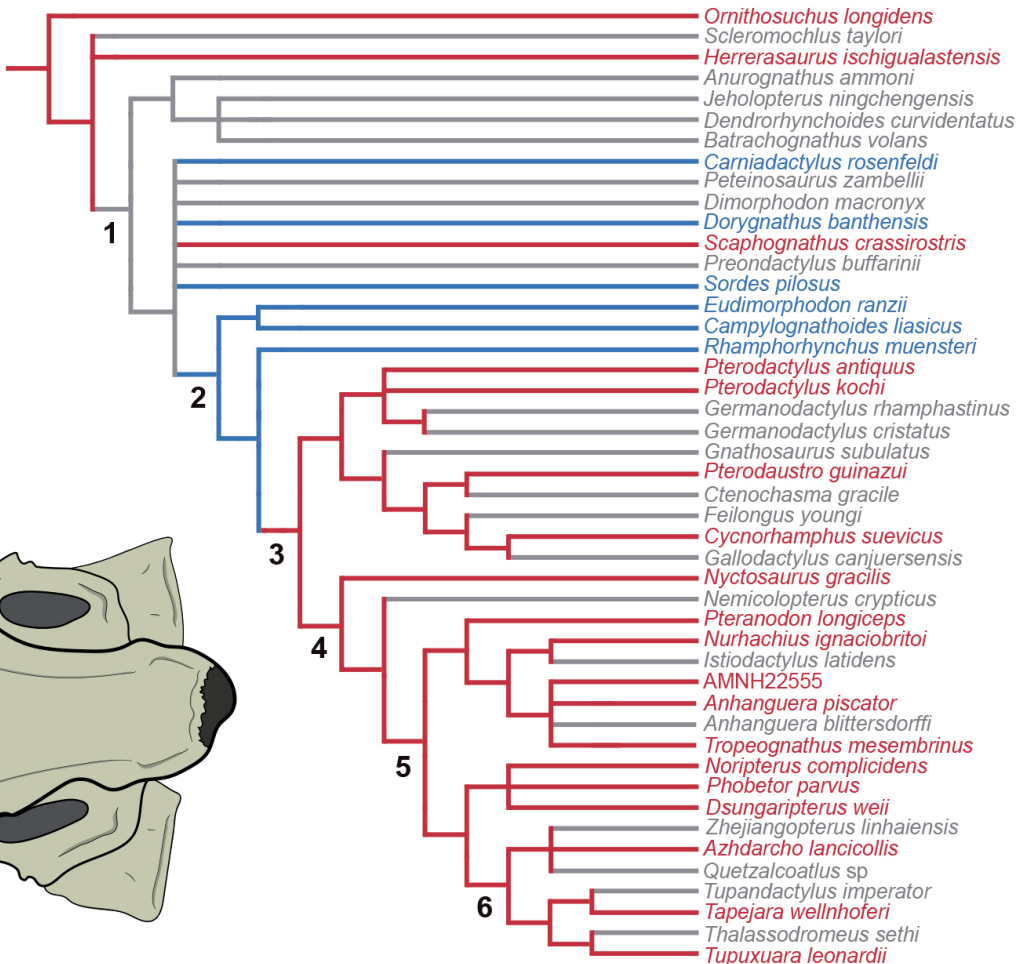

b
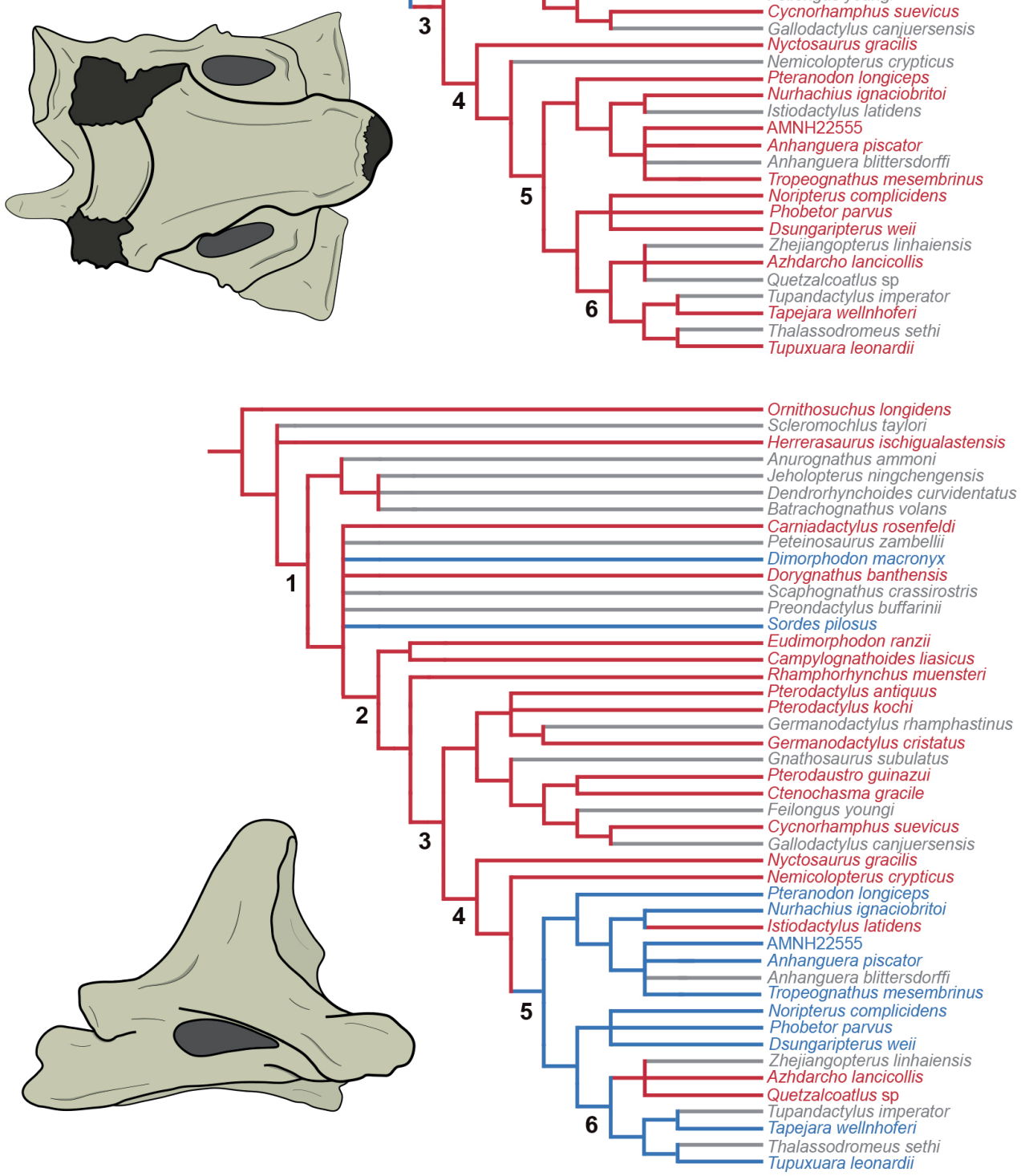

Figure 2 - Character evolution mapped on the strict consensus tree. a) Character 80. b) Character 81. Red, state 0 ; blue, state 1; gray, state unknown (missing data). 1, Pterosauria; 2, Novialoidea; 3, Pterodactyloidea; 4, Dsungaripteroidea; 5, Ornithocheiroidea; 6, Azhdarchoidea. 
a

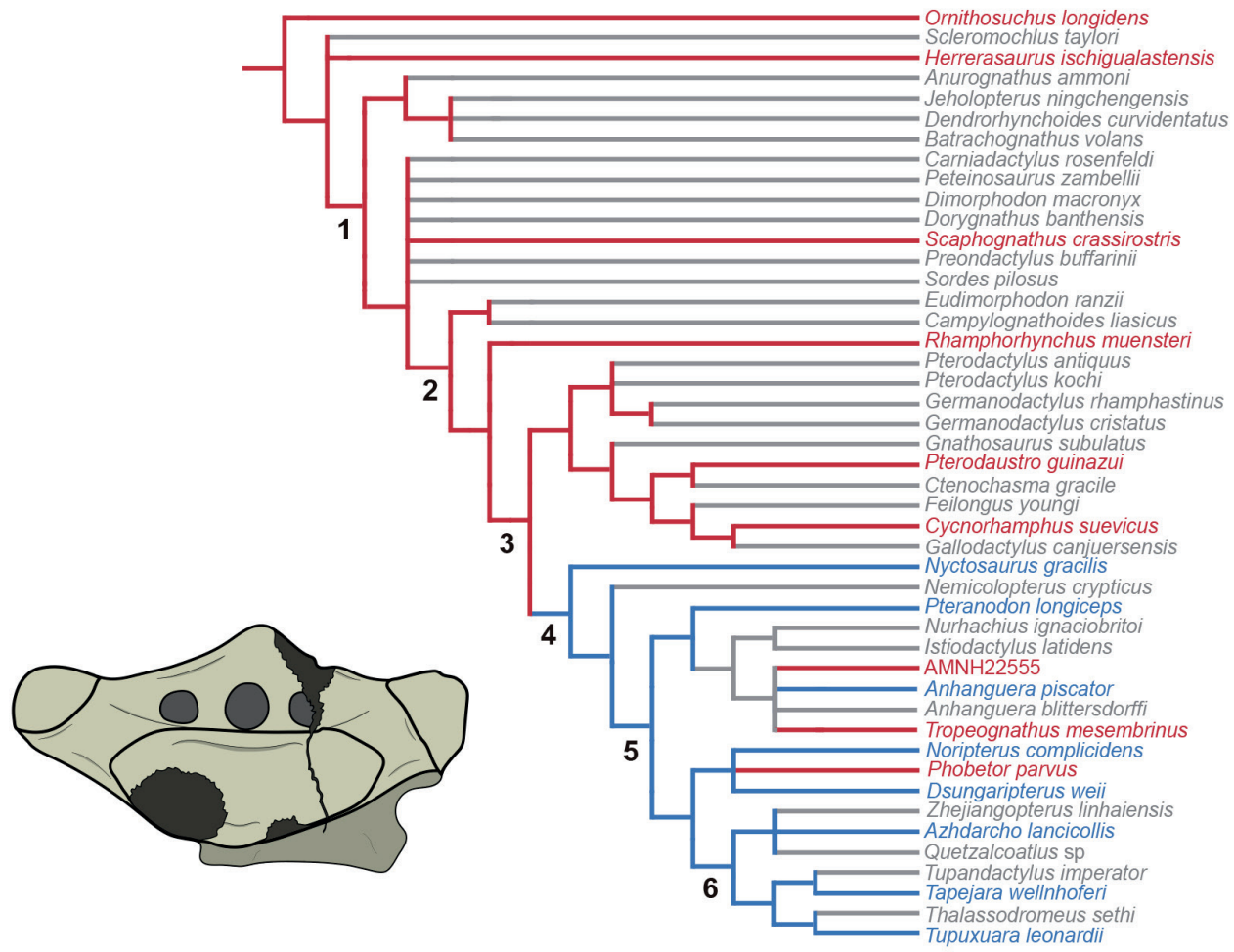

b

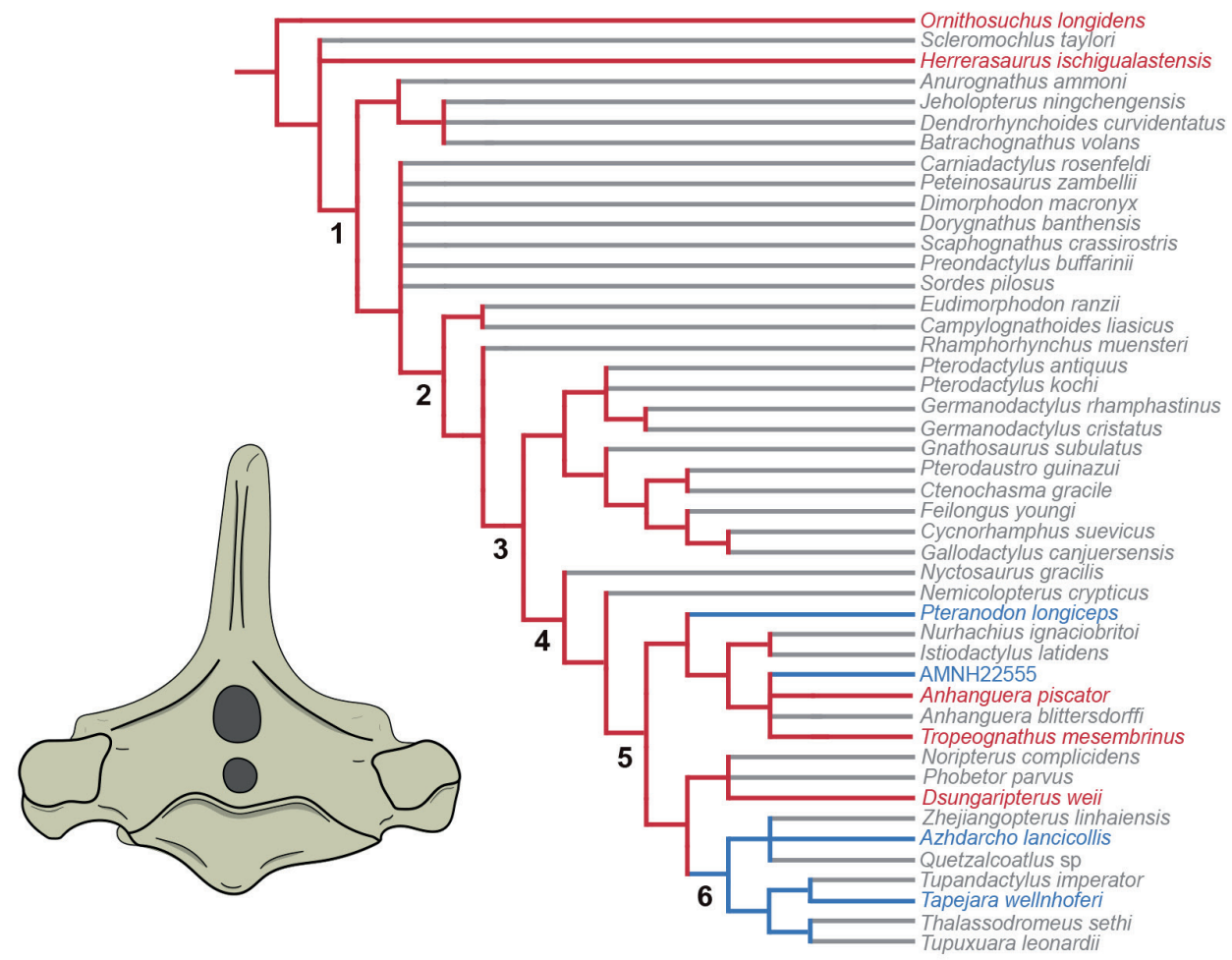

Figure 3 - Character evolution mapped on the strict consensus tree. a) Character 82. b) Character 83. Red, state 0; blue, state 1; gray, state unknown (missing data). 1, Pterosauria; 2, Novialoidea; 3, Pterodactyloidea; 4, Dsungaripteroidea; 5, Ornithocheiroidea; 6, Azhdarchoidea. 
absent, with the exception of some genera such as Rhamphorhynchus. However, pneumatic foramina on the lateral surface of the neural arch of the midcervical vertebrae (character 80 ) were present only in non-pterodactyloids. Bennett (2001) points out a peculiar pneumatic foramen on the base of the prezygapophysis, in similar position to the observed in non-pterodactyloids, only on the fourth cervical vertebra of the specimen YPM 2440, attributed to the genus Pteranodon; however, he also notes that there appears to be some variation in the position of the foramen, which possibly was originally positioned on the centrum.

Although the flattened preservation might have negatively influenced the observation of lateral pneumatic foramina in mid-cervicals (character 81 ) in non-dsungaripteroids, the analysis could be made in more than half of their species present in the matrix, and most of them lack this character (84.6\% of analyzed non-dsungaripteroids). In the Azhdarchidae, the absence of this pneumatic foramen has been previously described as a familylevel synapomorphy (Henderson and Peterson 2006, Averianov 2010). Although we did not observe the lateral foramen in mid-cervicals of Archaeopterodactyloidea, the literature records the presence of this foramen in Ctenochasmatidae pterosaurs, such as Gnathosaurus subulatus von Meyer, 1833. The presence of the lateral foramen in the mid-cervicals of the Ctenochasmatidae is considered an important character to distinguish their cervicals from the Azhdarchidae, since both present anatomical similarities, such as pronounced elongation (Andres and Qiang 2008).

The presence of lateral pneumatic foramina on posterior cervical vertebrae (character 84 ) was not as abundantly distributed as in mid-cervicals; this could be a bias due to the scarcity of known posterior cervical vertebrae in relation to midcervicals. The presence of lateral pneumatic foramina in mid-cervicals is independent from the ones in posterior cervicals: in two of the eight species in which both characters could be assessed, this variation was present: Pteranodon longiceps has lateral pneumatic foramina in the mid-cervicals but none in the posterior cervicals (Bennett 2001) and the opposite occurs in Rhamphorhynchus muensteri and Azhdarcho lancicollis (Bonde and Christiansen 2003, Averianov 2010).

The number of lateral pneumatic foramina on the centrum of cervical vertebrae (character 85 ) depends on their presence (that is, characters 81 and/or 84 being scored as 1), which certainly entails a low character presence rate in this analysis (inapplicable character in black in Figure 4b). The variation of the number of lateral foramina was observed only between the fifth and eighth cervical. Although recovered as a synapomorphy of the Anhangueridae, the presence of two or more lateral pneumatic foramina on the centrum in midand posterior cervical vertebrae is also reported in the Thalassodrominae (Vila Nova et al. 2015, Buchmann et al. 2018), suggesting a convergence in both clades.

The formation of the notarium in osteologically mature dsungaripteroids precludes the observation of the anterior and posterior faces of the vertebrae and, consequently, the coding of characters 82 and 83. The presence of pneumatic foramina on the lateral sides of the neural canal of the mid-cervical vertebrae (character state 82.1) was found as a synapomorphy of the Dsungaripteroidea, but in the rhamphorhynchid Sericipterus wucaiwanensis Andres et al., 2010, not included in this matrix, it is possible to notice the presence of foramina laterally to the neural canal in the third cervical of the specimen (Andres et al. 2010), which suggests an independent origin. These pneumatic foramina adjacent to the neural canal in mid-cervical vertebrae usually exhibit small size in relation to the neural canal, but this condition varies. This is the case of the Azhdarchoidea, in which the pneumatic foramina adjacent to the neural canal in the mid-cervicals of Tapejara wellnhoferi Kellner, 
a

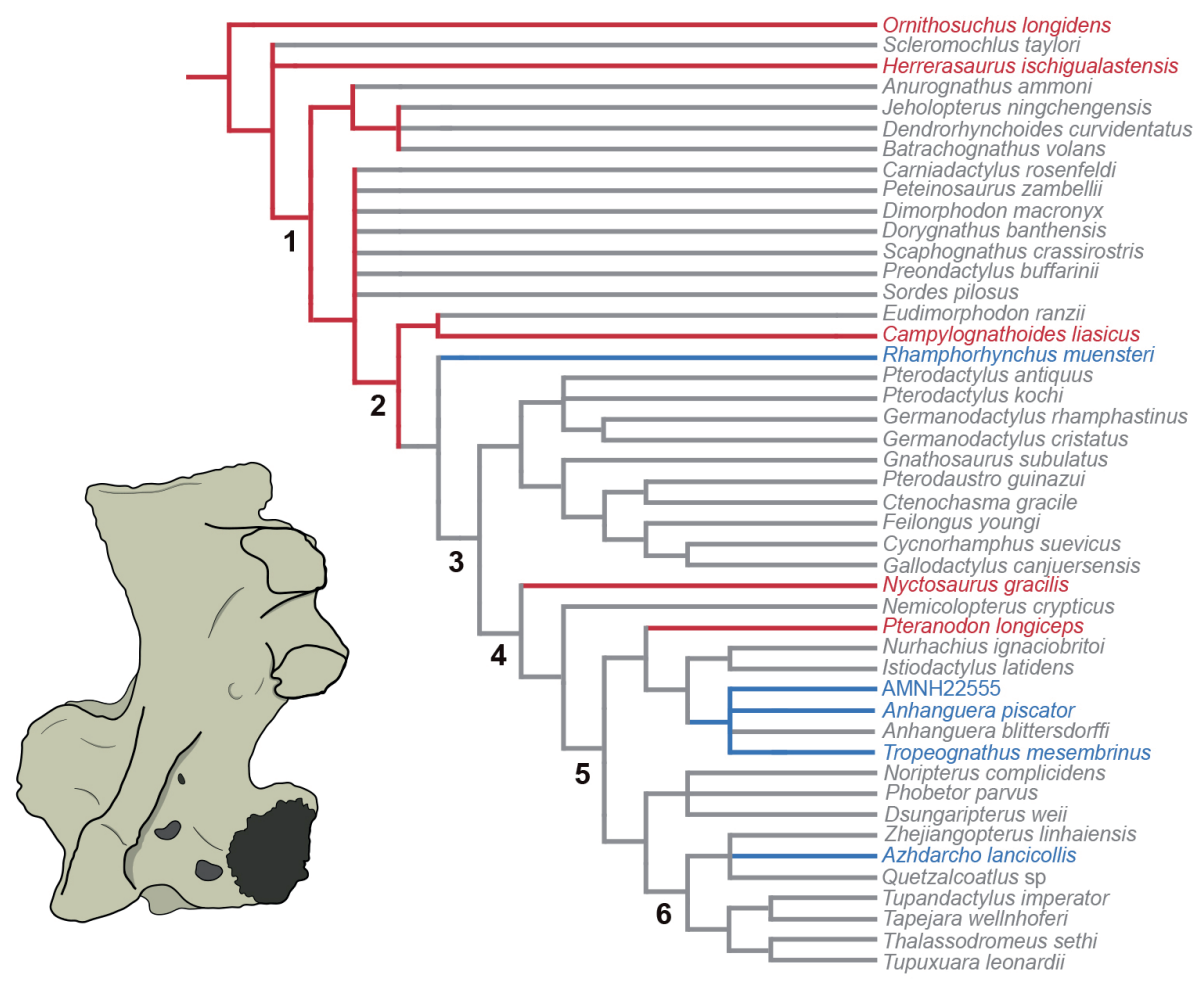

b

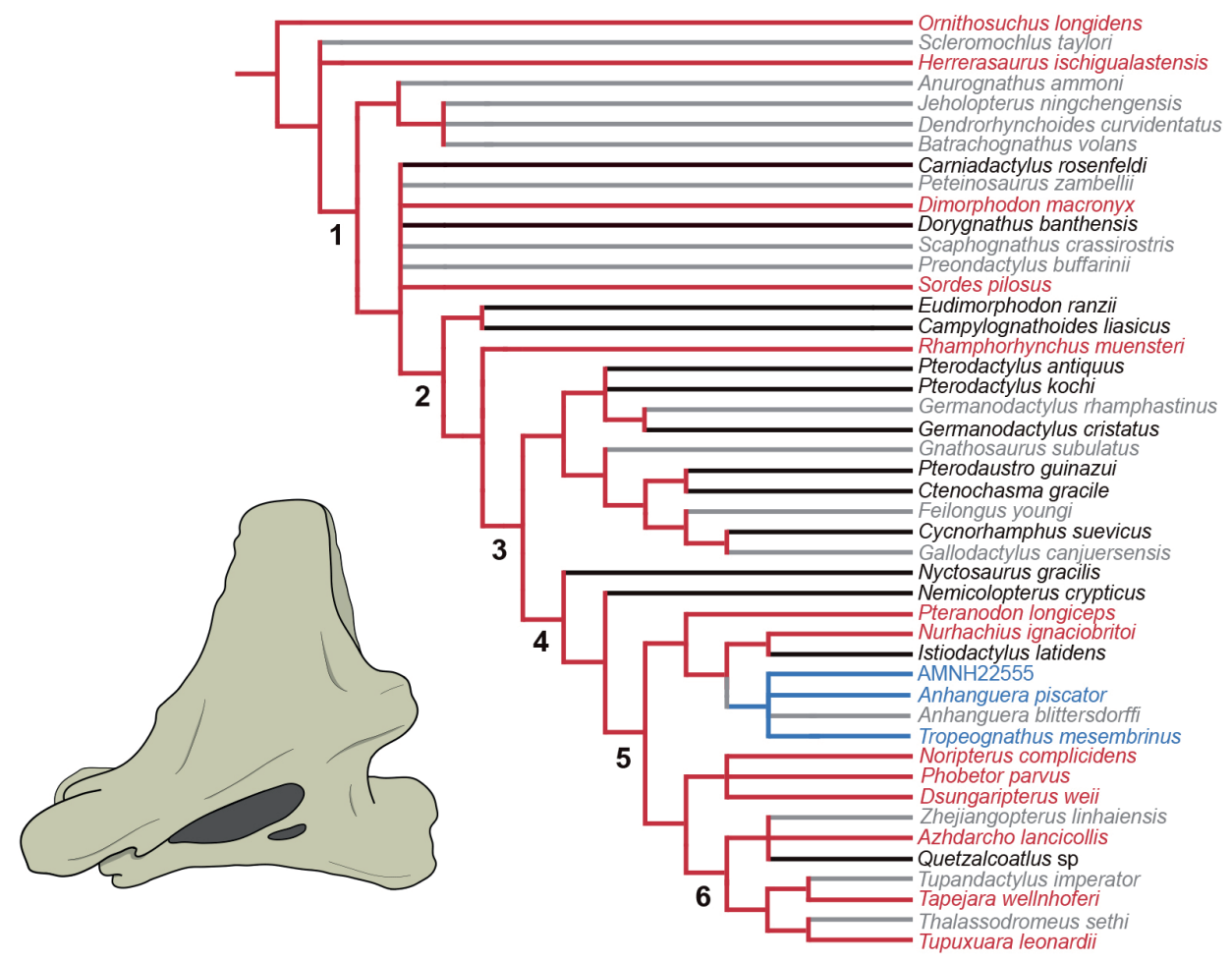

Figure 4 - Character evolution mapped on the strict consensus tree. a) Character 84. b) Character 85. Red, state 0 ; blue, state 1; gray, state unknown (missing data); black, inapplicable character. 1, Pterosauria; 2 , Novialoidea; 3, Pterodactyloidea; 4, Dsungaripteroidea; 5, Ornithocheiroidea; 6, Azhdarchoidea. 
a

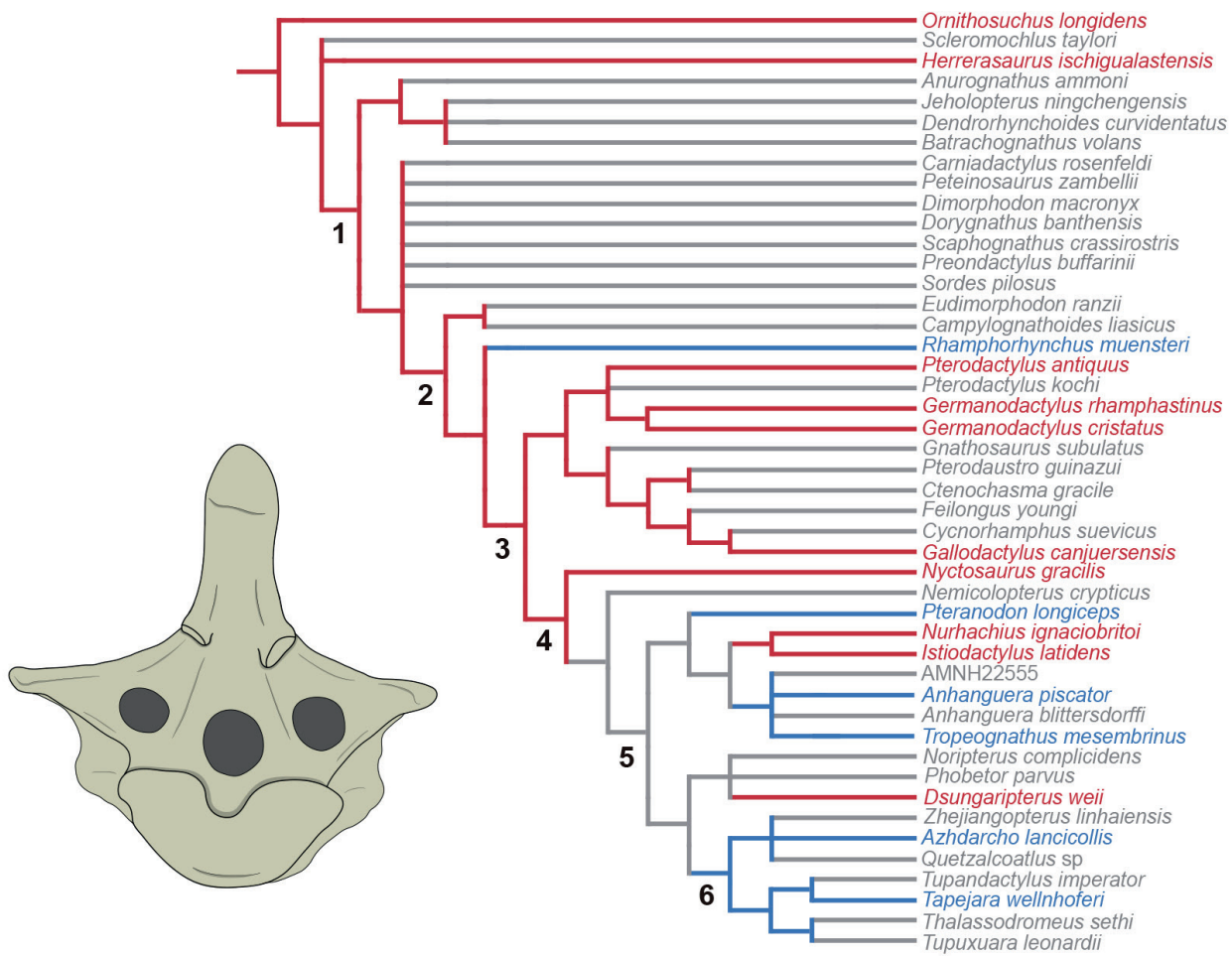

b

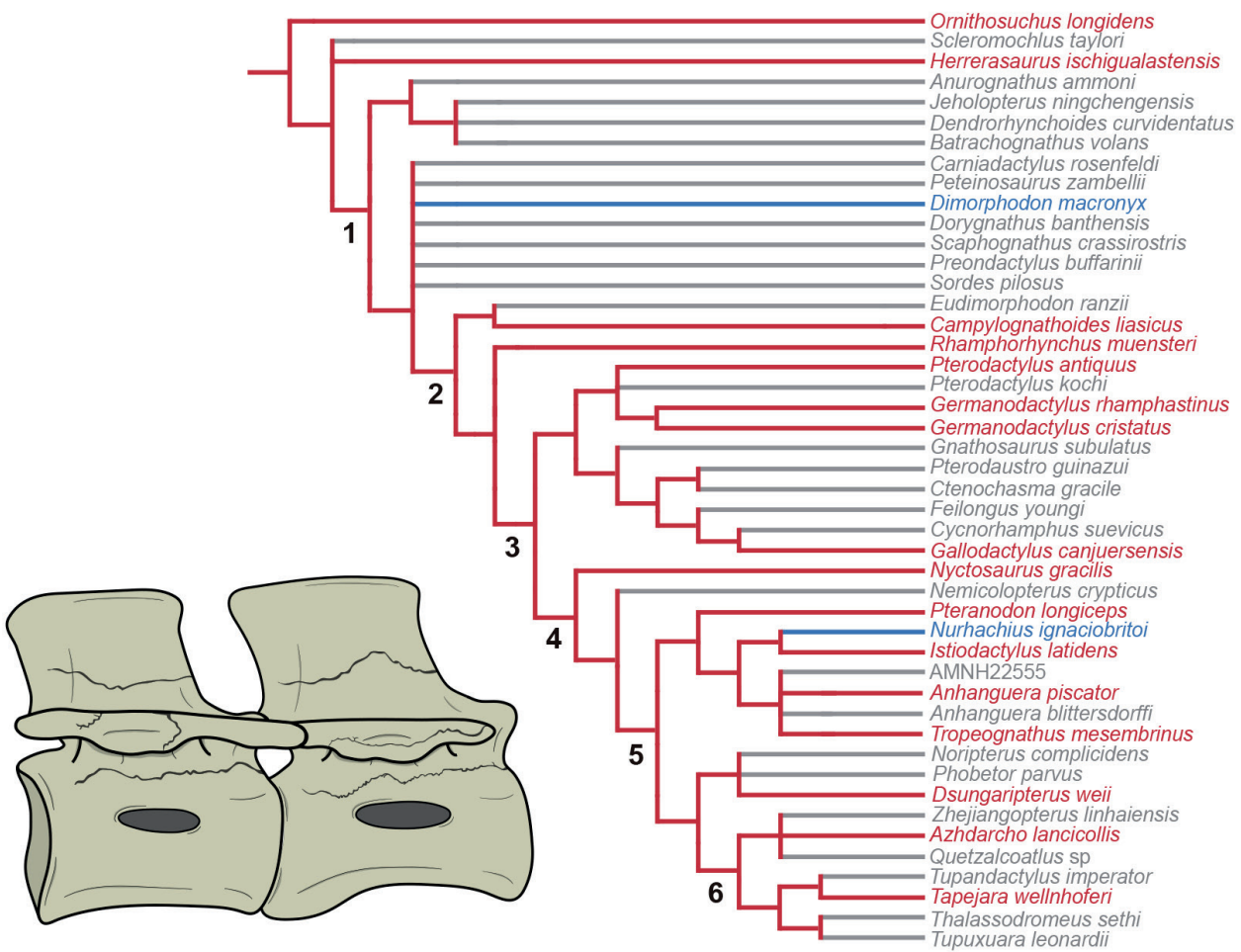

Figure 5 - Character evolution mapped on the strict consensus tree. a) Character 86. b) Character 87. Red, state 0; blue, state 1; gray, state unknown (missing data). 1, Pterosauria; 2, Novialoidea; 3 , Pterodactyloidea; 4, Dsungaripteroidea; 5, Ornithocheiroidea; 6, Azhdarchoidea. 
1989 are comparatively smaller than those seen in Azhdarcho lancicollis (Averianov 2010, Eck et al. 2011). The size of the pneumatic foramina in different vertebrae of a sequence also present variation, as seen in Azhdarcho lancicollis, which has pneumatic foramina adjacent to the neural canal in cervical VI comparatively smaller than in cervical VII (Averianov 2010), which seems to be natural variations along the neck.

Also, asymmetry is present in at least some species of Dsungaripteroidea, such as tapejarids and anhanguerids, including variations in the number and sizes of pneumatic foramina adjacent to the the neural canal or on the lateral sides of the centra (Wellnhofer 1991, Vila Nova et al. 2015, Buchmann et al. 2018). Such condition demonstrates that a pronounced asymmetry of pneumatic foramina was common in this clade.

When present, the notarium of the species analyzed frequently did not present pneumatic foramina on the base of transverse processes (Bennett 2001, Averianov 2010, Kellner et al. 2013), but was observed in the free dorsal vertebrae. In other specimens described in the literature pneumatic foramina are absent in the notarium, as in MN 6588-V, identified as Tapejaridae indet. (Sayão and Kellner 2006).

The presence of pneumatic fossae on the bases of the transverse processes is relatively common in the free dorsal vertebrae of novialoids. Association of these fossae to pneumatic foramina varies, though. They are associated in Rhamphorhynchus muensteri, but not in Sericipterus wucaiwanensis, another rhamphorhynchid (Bonde and Christiansen 2003, Andres et al. 2010). Those pneumatic fossae are limited by laminar structures and were probably associated with soft tissues.

Although pneumatic foramina on the centrum of the dorsal vertebrae (character 87) were present only in two of the analyzed species, they were reported previously in other non-pterodactyloids, such as Raeticodactylus filisurensis Stecher, 2008, suggesting independent origins (Butler et al. 2009). As character 85 , character 87 also is observed only in free dorsals (Butler et al. 2009, Wang et al. 2005).

\section{CONCLUSION}

According to the analysis, only character states 82.1 and 85.1 appeared only once among pterosaurs, but both have already been reported in the literature as present in other species that are currently not incorporated into this matrix, such as in Sericipterus wucaiwanensis and some thalassodromines (Andres et al. 2010, Vila Nova et al. 2015, Buchmann et al. 2018), which once again points to independent origins. All other characters showed at least one convergent acquisition, most of them within the Dsungaripteroidea.

Pneumatic foramina along the vertebral column were more common in the Dsungaripteroidea. In non-dsungaripteroids, most foramina were acquired through convergent evolution. However, most of these species are not three-dimensionally preserved, preventing the observation of many features and boosting the number of missing data in the matrix.

\section{ACKNOWLEDGMENTS}

This work was supported by a joint Conselho Nacional de Desenvolvimento Científico e Tecnológico (CNPq) and Fundação de Amparo à Pesquisa e Inovação do Espírito Santo (FAPES) grant (\#52986870/2011 to TR). The authors would like to thank Dr. Luciana Carvalho (Museu Nacional/UFRJ) for receiving us in the collection. Special thanks to Dr. Leonardo dos Santos Avilla and Dr. Celso Oliveira Azevedo, who greatly helped on discussions about scientific methodology, and to Dr. Felipe Pinheiro and an anonymous reviewer, who greatly improved the manuscript.

\section{AUTHOR CONTRIBUTIONS}

Richard Buchmann idealized the project, proposed the characters, performed the experiments, 
interpreted the data, wrote and reviewed the paper, edited the figures. Taissa Rodrigues idealized the project, proposed the characters, interpreted the data, wrote and reviewed the paper.

\section{REFERENCES}

ANDRES B, CLARK J AND XU X. 2010. A new rhamphorhynchid pterosaur from the Upper Jurassic of Xinjiang, China, and the phylogenetic relationships of basal pterosaurs. J Vertebr Paleontol 30(1): 163-187.

ANDRES B, CLARK J AND XU X. 2014. The earliest pterodactyloid and the origin of the group. Curr Biol 24: $1-6$.

ANDRES B AND QIANG J. 2008. A new pterosaur from the Liaoning Province of China, the phylogeny of the Pterodactyloidea, and convergence in their cervical vertebrae. Palaentol 51(2): 453-469.

AVERIANOV AO. 2010. The osteology of Azhdarcho lancicollis Nessov, 1984 (Pterosauria, Azhdarchidae) from the Late Cretaceous of Uzbekistan. Proc Zool Inst RAS 314(3): 264-317.

BENNETT SC. 2001. The osteology and functional morphology of the Late Cretaceous pterosaur Pteranodon. Part I General Description of Osteology. Paleontogr Abt A 260: 1-112.

BONDE N AND CHRISTIANSEN P. 2003. The detailed anatomy of Rhamphorhynchus: axial pneumaticity and its implications. Geol Soc Spec Publ 217: 217-232.

BUCHMANN R, RODRIGUES T, POLEGARIO S AND KELLNER AWA. 2018. New information on the postcranial skeleton of the Thalassodrominae (Pterosauria, Pterodactyloidea, Tapejaridae). Hist Biol 30: 1139-1149

BUTLER RJ, BARRETT PM AND GOWER DJ. 2009. Postcranial skeletal pneumaticity and air-sacs in the earliest pterosaurs. Biol Letters 5: 557-560.

BUTLER RJ, BARRETT PM AND GOWER DJ. 2012. Reassessment of the evidence for postcranial skeletal pneumaticity in Triassic archosaurs, and the early evolution of the avian respiratory system. PLoS ONE 7: e34094.

CLAESSENS LPAM, O'CONNOR PM AND UNWIN DM. 2009. Respiratory evolution facilitated the origin of pterosaur flight and aerial gigantism. PLoS ONE 4: e4497.

DE PINNA MGG. 1991. Concepts and tests of homology in the cladistics paradigm. Cladistics 7: 367-394.

ECK K, ELGIN RA AND FREY E. 2011. On the osteology of Tapejara wellnhoferi Kellner 1989 and the first occurrence of a multiple specimen assemblage from the Santana Formation, Araripe Basin, NE-Brazil. Swiss J Palaeontol 130: $277-296$

FOREY PL AND KITCHING IJ. 2000. Experiments in coding multistate characters. In: Homology and Systematics, Coding characters for phylogenetic analysis, London: Taylor \& Francis, London, p. 54-80.
GOLOBOFF P, FARRIS S AND NIXON K. 2008. TNT, a free program for phylogenetic analysis. Cladistics 24: 774-786.

HAWKINS J. 2000. A survey of primary homology assessment: different botanists perceive and define characters in different ways. In: Homology and Systematics, Coding characters for phylogenetic analysis, London: Taylor \& Francis, London, p. 22-53.

HENDERSON MD AND PETERSON JE. 2006 An azhdarchid pterosaur cervical vertebra from the hell creek formation (Maastrichtian) of southeastern Montana. J Vertebr Paleontol 26(1): 192-195.

KELLNER AWA. 2003. Pterosaur phylogeny and comments on the evolutionary history of the group. Geol Soc Spec Publ 217: 105-137.

KELLNER AWA, CAMPOS DA, SAYÃO JM, SARAIVA AAF, RODRIGUES T, OLIVEIRA G, CRUZ LA, COSTA FR, SILVA HP AND FERREIRA JS. 2013. The largest flying reptile from Gondwana: a new specimen of Tropeognathus cf. T. mesembrinus Wellnhofer, 1987 (Pterodactyloidea, Anhangueridae) and other large pterosaurs from the Romualdo Formation, Lower Cretaceous, Brazil. An Acad Bras Cienc 85: 113-135.

KELLNER AWA AND TOMIDA Y. 2000. Description of a new species of Anhangueridae (Pterodactyloidea) with comments on the pterosaur fauna from the Santana Formation (Aptian-Albian), Northeastern Brazil. Tokyo: National Science Museum, Monographs, 135 p.

MADDISON WP AND MADDISON DR. 2015. Mesquite. A modular system for evolutionary analysis. v. 3.03. MÜLLER B. 1908. The air-sacs of the pigeon. Smith Misc College 50: 365-414.

NESBITT SJ. 2011. The early evolution of archosaurs: relationships and the origins of major clades. B Am Mus Nat Hist 352: 291.

O'CONNOR PM. 2006. Postcranial pneumaticity: an evaluation of soft-tissue influences on the postcranial skeleton and the reconstruction of pulmonary anatomy in archosaurs. J Morphol 267: 1199-1226.

PINHEIRO FL AND RODRIGUES T. 2017. Anhanguera taxonomy revisited: is our understanding of Santana Group pterosaur diversity biased by poor biological and stratigraphic control? PeerJ 5: e3285.

SAYÃO JM AND KELLNER AWA. 2006. Novo esqueleto parcial de pterossauro (Pterodactyloidea, Tapejaridae) do Membro Crato (Aptiano), Formação Santana, Bacia do Araripe, Nordeste do Brasil. Estudos Geológicos 16: 1640.

UNWIN DM. 2003. On the phylogeny and evolutionary history of pterosaurs. Geol Soc Spec Publ 217: 139-190.

VILANOVABC, SAYÃO JM, LANGER MC AND KELLNER AWA. 2015. Comments on the cervical vertebrae of the Tapejaridae (Pterosauria, Pterodactyloidea) with description of new specimens. Hist Biol 27: 770-780. 
WANG X, KELLNER AWA, ZHOU Z AND CAMPOS DA. 2005. Pterosaur diversity and faunal turnover in Cretaceous terrestrial ecosystems in China. Nature 437: 875-879.

WANG X, KELLNER AWA, ZHOU Z AND CAMPOS DA. 2008. Discovery of a rare arboreal forest-dweling flying reptile (Pterosauria, Pterodactyloidea) from China. Proc Natl Acad Sci U S A 105(6): 1983-1987.
WELLNHOFER P. 1975. Die Rhamphorhynchoidea (Pterosauria) der Oberjura-Plattenkalke Süddeutschlands. I: Allgemeine Skelettmorphologie. Paleontogr Abt A 148: 132-186.

WELLNHOFER P. 1991. Weitere Pterosaurierfunde aus der Santana-Formation (Apt) der Chapada do Araripe, Brasilien. Paleontogr Abt A 215: 43-101. 